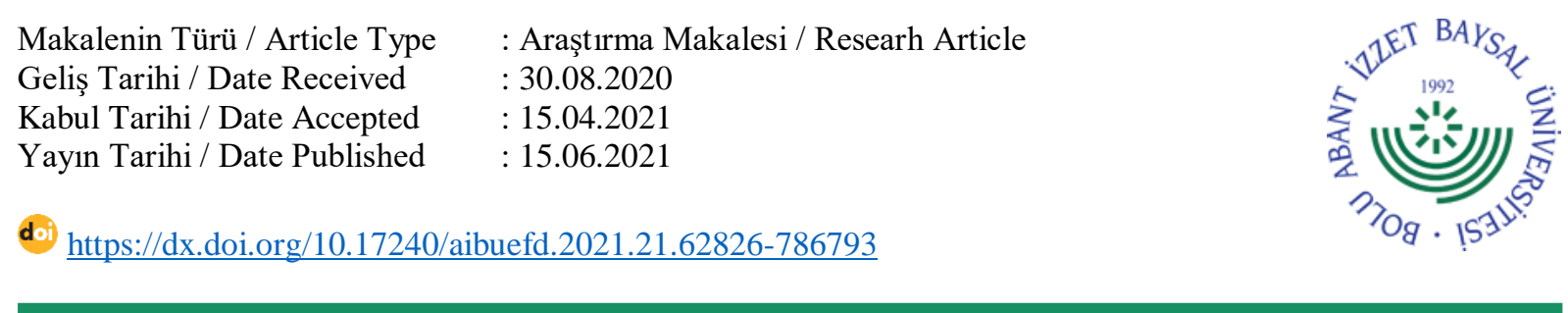

\title{
PSİKOLOJİK DANIŞMANLARIN YAS DANIŞMANLIĞINA İLIŞKİN DEĞERLENDİRMELERİ
}

\author{
Yelda YILDIZ ÖNAL ${ }^{1}$, Serhat Armağan KÖSEOĞLU²
}

ÖZ

$\mathrm{Bu}$ araştırma ile psikolojik danışmanların yas danışmanlığına yönelik algılarını, deneyimlerini ve Türkiye'deki uygulamalara ilişkin değerlendirmelerini ortaya koymak amaçlanmıştır. Araştırmada, nitel araştırma deseninde yer alan fenomenolojik yöntem kullanılmıştır. Çalışma grubunda, ölçüt örnekleme yöntemine göre belirlenen, İstanbul'da ikamet eden 10 psikolojik danışman yer almıştır. Veriler, yarı yapılandırılmış görüşme tekniği ile yöneltilen sorular yoluyla elde edilip, betimsel analiz ve içerik analizi kullanılarak çözümlenmiştir. Araştırma sonuçlarına göre, katılımcılar yas ile çalışmayı mesleki süreçte her an karşılarına çıkabilecek bir durum olarak gördüklerini; yasın sadece ölümle ilişkilendirilmediğini; yas danışmanlığı kavramının profesyonel yardım sürecini sınırlandırdığını; özel olarak, yas danışmanlığı yardım talebiyle gelinmese bile çalışılan konuların altında gecikmiş, ertelenmiş yasın çıkabildiğini ve kendilerine yakın buldukları kuramsal yaklaşım ve teknikleri kullanmayı tercih ettiklerini belirtmişlerdir. Ayrıca, kişisel deneyimleri, yetkinlikleri ve değerlendirmeleri üzerinden yas danışmanlığına ilişkin varoluşsal açıklama getirdikleri; yas sürecini kültürel ve toplumsal faktörlerle nitelendirdikleri; mesleki açıdan aldıkları eğitimi yasla çalışmak için yeterli bulmadıklarını; kuramsal ve uygulamalı derslere ve eğitimlere ağırlık verilmesi gerekliliğini vurguladıkları ortaya konmuştur.

Anahtar Kelimeler: Kayıp, yas, yas danışmanlığı

\section{EVALUATIONS OF PSYCHOLOGICAL COUNSELORS ON GRIEF COUNSELING}

\begin{abstract}
The aim of this study is to reveal the perceptions and experiences of psychological counselors regarding grief counseling and their evaluations regarding practice in Turkey. In the study, a phenomenological method, which is a qualitative research design, was used. The study group was determined by the criterion sampling method and all participants in the group reside in Istanbul. The data were obtained through questions posed by the semi-structured interview technique. Descriptive analysis and content analysis were used to analyze the data. According to the results of the research, the participants consider working with grief as a situation that they may encounter at any time in the professional process. They reported that grief cannot be associated only with death and the grief counseling concept limits the professional help process, even if the grief counseling was not requested with special help, delayed and deferred grief could emerge under the subjects studied. Participants stated that they prefer to use theoretical approaches and techniques close to them. It was determined that participants accounted for an existential explanation based on personal experiments, competencies and evaluations regarding grief counseling. In addition, they described the grief process with cultural and social factors, and they did not find the education they received professionally sufficient to work with grief. Finally, they emphasized the necessity of focusing on theoretical and practical courses and educations.
\end{abstract}

Keywords: Bereavement, grief, grief counseling

\footnotetext{
${ }^{1}$ Ístanbul Medipol Üniversitesi, Eğitim Fakültesi, yeldayildiz@medipol.edu.tr, 는ttps://orcid.org/0000-0002-2397-4778

${ }^{2}$ İstanbul Üniversitesi-Cerrahpaşa, Hasan Ali Yücel Eğitim Fakültesi, armagany@iuc.edu.tr, 느ttps://orcid.org/0000-0001-7794-9650
} 


\section{GíRiş}

Evrensel bir olgu olan ölüm, yaşamın geri dönüşü olmayan kaçınılmaz bir gerçeğidir. Sevilen bir kişinin ölümüne bağlı olarak yaşanılan kayıp sonrasında, yoğun acı, üzüntü ve kederle gelen yas süreci bireylerin hayatında karşı karşıya kaldıkları en sarsıcı yaşam olayı olarak görülmektedir. Gizir'e göre (2006) yas, sevilen birinin ölümünden sonra kayıp yaşayan bireyler tarafından gösterilen fiziksel, duygusal, bilişsel ve davranışsal tepkiler olarak nitelendirilebilir. Yas, kayba verilen bir tepkidir ve kişinin hayatına normal ve sağlıklı devam edebilmesi için yasını tutması, yas sürecini tamamlaması gerekmektedir. Kişi, yas tutma süreci sonunda yaşadığı kaybı yaşamının bir parçası haline getirerek bununla yaşamayı öğrenmektedir (Zara, 2011).

Yas, kayıp yaşayan kişinin hayatının her alanını ilgilendiren çok boyutlu zor bir süreç olmasına rağmen bir hastalık değildir. Yas, kayba karşı gelişen doğal bir tepkidir (Bildik, 2013), duygulanımdır. Yası, 'bizim için çok fazla önemi olan birisini sonsuza dek kaybettĭgimizde hissettiğimiz üzüntüden doğan duygular' olarak tanımlamak mümkündür (Yıldız, 2004). Son yıllarda ilgili literatürde ele alınan konulardan yas süreci ve yas danışmanlığı, psikolojik yardım mesleklerinde dikkatlerin çevrildiği bir konu olmuştur. Freud'un (1917) Yas ve Melankoli eseriyle çalışılmaya başlanan yas, Kübler-Ross, Rondo, Lindemann tarafindan ele alınmış, ölüm ve sonrası yas sürecindeki evrelerin tanımlanmasıyla literatüre katkı sağlamış ve özellikle Worden'ın çalışmalarıyla psikolojik danışmanlık sürecinde terapötik bağlamda uygulamalı çalışmalarla kendini göstermiştir. Farklı yaklaşımlar tarafindan yas terapisi ve/veya yas danışmanlığı olarak da adlandırılan süreçte alana katkı sağlayan kuramcılar ve uygulamacılar yası normal, karmaşık ve travmatik olarak isimlendirmiştir (Bildik, 2013; Genlik, 2012). İlgili literatürde danışmanlık sürecinin daha çok travmatik ve karmaşık yas sürecine odaklandığı ve kayıp ve yas döngüsünde, bireylerin kaybedilen kişinin varlığı olmaksızın yeni yaşama uyum sağlayabilmesinde profesyonel yardımın ve psikolojik danışma almanın öneminin vurgulandığ 1 görülmektedir (Worden, 2018). Yas danışmanlığında, psikolojik danışmanın rolü, yas tutan bireye, ölen kişi ile ilişkisini sonlandırmaktan öte, bu bireyin duygusal yaşam alanında ölen kişiye uygun bir yer bulmasına ve yaşamını etkin bir birey olarak devam ettirmesine yardımcı olmaktır (Gizir, 2006).

Psikolojik danışmanlar, farklı gelişim dönemlerinde farklı uyum sorunları yaşayan bireylerle çalışmakta olan meslek elemanlarıdır. Mesleğini sürdüren alan çalışanlarının lisans eğitimi ve sonrasında aldıkları eğitimler, çalı̧̧maya başladıktan sonra karşılaştıkları sorunların çeşitliliği, mesleki bilgi ve yeterliliklerine ilişkin değerlendirme yapabilmelerini mümkün kılmaktadır. Kalay-Usta (2020), çalışmasında psikolojik danışmanların mesleki gelişim sürecinde mesleki bilgi ve yeterliliklerini arttırmayı, psikolojik danışma becerilerini güçlendirmeyi ve kariyer ruh sağlığı uyumunu geliştirmeyi önemsediklerini ortaya koymaktadır. Psikolojik danışmanlar için 'etkili psikolojik danışman niteliklerini' arttırmak önemli bir değişken olarak görülmektedir (Buyruk Genç, 2019).Yaşamın herhangi bir anında, sevilen bir kişinin kaybının ardından görülen yas sürecine eşlik eden olumsuz yaşantıların, bilişsel, duygusal, davranışsal, fiziksel ve kültürel tepkilerin üzerinden yaşanması, bireylerin uyumu, yaşam doyumu ve psikolojik sağlamlığına olan etkileri nedeniyle danışmanlık mesleğinin önemini kayıp ve yas sürecinde daha da fazla ortaya çıkarmaktadır.

Psikolojik danışmanların mesleki bilgi, beceri ve yeterliliklerine bağlı olarak çalıştıkları sorun alanlarına yönelimleri zaman zaman farklılaşmaktadır. Söz konusu yönelimler beraberinde, karşılaşılan soruna ilişkin mesleki tanım getirmelerini de sağlamaktadır. Sorunun karşılaşılma sıklı̆ı, literatürdeki gelişmeler, yeni modellerin, teknik ve yöntemlerin ortaya çıkışı psikolojik danı̧̧manların bu yönelimlerini belirleyebilmektedir. 2000 'li yıllardan sonra yas danışmanlığı ile ilgili yapılan araştırma, yayın, uygulamaların sınırlı sayıda olduğu ve çoğunlukla çocuklar, ergenler, anne-babalar üzerinde yapıldı ğı görülmektedir. Güven vd. (2009) tarafından, Türk Psikolojik Danışma ve Rehberlik Dergisinde yayınlanan makalelerin çeşitli özellikler açısından incelendiği çalı̧̧ada, derginin ilk otuz sayısındaki 198 makale incelenmiştir. Sonuçta, evlilik ve mesleki rehberlik konularında yapılan çalışmaların, betimsel araştırmaların ve tek yazarlı çalışmaların diğerlerine göre daha fazla olduğu tespit edilmiştir. 59 farklı konuda yer alan makalelerin içinde yalnızca iki makale yas danışmanlığı konusunda yapılmıştır. Yine, Seçer vd. (2014) tarafindan, Türkiye'de 2007-2011 yılları arasında RPD alanında yayınlanmış 250 makale incelenmiştir. İncelenen yayınlar arasında, yas danışmanlığı ile ilgili yapılmış bir çalı̧̧maya rastlanmamış olması dikkat çekicidir. Nitekim ilgili literatür incelendiğinde Türkiye'de yas danışmanlığı uygulamalarına yönelik çalışmaların sınırlı sayıda olduğu görülmüştür (Çiftçiler Aydın, 2020; Genç \& Aydın, 2015; Gizir, 2006). Bu durum yas danışmanlığı ile ilgili araştırmaların yetersiz olduğunu ve araştırma yapılmasına gereksinim duyulduğunu düşündürmektedir. Danışan gören psikolojik danışmanların ise yas danışmanlığı konusunu nasıl ele aldığına, bu başlıkta ne tür çalışmalar yaptıklarına ve yas danışmanlığına yönelik algılarına ilişkin değerlendirme yapılması gereksinimini doğurmuştur. Bu amaçla, söz konusu araştırmada psikolojik danışmanların yas sürecine ilişkin tanımları, mesleki bağlamda kendilerine ilişkin duygu, düşünce ve deneyimleri, psikolojik danışma açısından yas danışmanlığına ilişkin bilgi, beceri ve yeterliliklerine yönelik değerlendirmelerini incelemek araştırmanın problemini oluşturmuş̧tur. 


\section{YÖNTEM}

\subsection{Araştırmanın modeli}

Araştırmanın amacını gerçekleştirmek için nitel araştırma geleneğinde yer alan fenomenolojik yöntem kullanılmıştır. Nitel araştırma, bir olgunun betimlenmesi, yorumlanması ve anlaşılmasını küçük bir çalışma grubuyla hedeflemektedir (Henwood, 1996). Bu gelenekte yer alan fenomenolojik yöntem de açık olay ya da davranışları tanımlamak yerine katılımcıların deneyimledikleri anlamlara odaklanmayı amaçlamaktadır (Senter \& Caldwell, 2002).

\subsection{Araştırmanın çalışma grubu}

Ölçüt örnekleme yöntemiyle oluşturulan çalışma grubunda 10 psikolojik danışman yer almıştır. Çalışma grubunun oluşturulmasında katılımcıların İstanbul'da ikamet etmesi, katılımcıların psikolojik danışmanlık (PD) merkezinde aktif danışan görmesi ve mesleki deneyimlerinin en az iki yıl olması kriterleri dikkate alınmıştır. Katılımcı sayısında, veri doygunluğuna ulaşılması belirleyici olmuştur. Tablo 1'e göre katılımcıların dördü kadın, altısı erkektir. İkisi PD merkezinde; altısı okulda ve PD merkezinde; ikisi Rehberlik ve Araştırma Merkezinde (RAM) ve PD merkezinde çalışmaktadır. Üçü lisans, beşi yüksek lisans mezunuyken ikisi doktora eğitimine devam etmektedir. Ayrıca katılımcıların sıklıkla çalıştıkları kitle, kullanmayı tercih ettikleri terapi yaklaşımları ve çalışma yıllarına dair bilgiler Tablo 1'de yer almaktadır. Katılımcılar 'K' koduyla tanımlanmıştır.

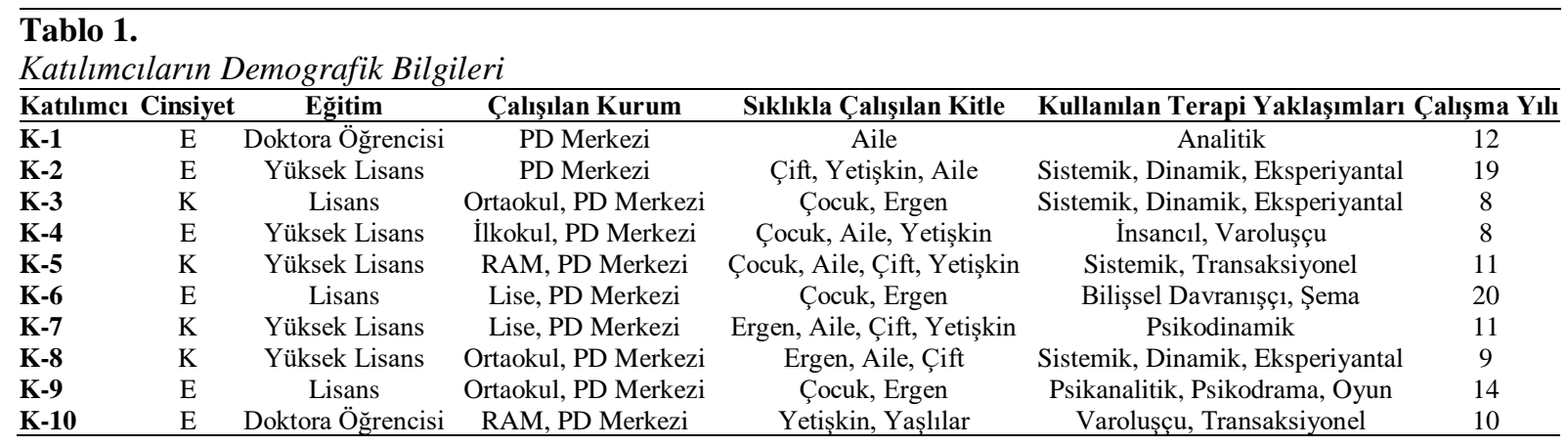

\subsection{Veri toplama araçları ve süreci}

$\mathrm{Bu}$ araştırmada fenomenolojik yöntemde yararlanılan yarı yapılandırılmış görüşme tekniği kullanılmıştır. Araştırmacılar tarafından hem demografik bilgileri hem de katılımcıların yas danışmanlığına yönelik algılarını, deneyimlerini ve Türkiye'deki uygulamalarla ilgili değerlendirmelerini ortaya koyabileceği düşünülen sorular, ilgili literatürden yararlanılarak oluşturulmuştur. Öncelikli olarak gönüllü iki psikolojik danışmanla ön görüşme yapılarak soruların anlaşılırlığı ve işlevselliği araştırmacılar tarafından değerlendirilmiş ve bazı sorular elenerek yarı yapılandırılmış görüşme sorularının son şekli verilmiştir. Katılımııların kişisel bilgilerine ulaşmak amacıyla cinsiyet, yaş, eğitim düzeyi, meslekte çalışma yılı, çalışılan kitle, çalışılan kurum/merkezler ile ilgili sorular sorulmuştur. Araştırmacı, araştırmanın örnekleme kriterlerine uyan tanıdık, gönüllü psikolojik danışmanlarla ve bu katılımcılardan bazılarının yönlendirdiği psikolojik danışmanlarla, onlara uyan zaman diliminde ve ortamda yüz yüze görüşme yapmıştır. Öncelikle katılımcılara araştırmanın amacı ve uygulama aşamalarıyla ilgili bilgi verilmiş, daha sonra katılımcıların izni doğrultusunda ses kaydı yapılarak yarı yapılandırılmış bireysel görüşmeler gerçekleştirilmiştir. Görüşmeler 15-60 dakika sürmüştür. Görüşmeler esnasında araştırmacı doğal gözlem de yapmıştır.

\subsection{Verilerin analizi}

Araştırma kapsamında, genel olarak nitel veri analizinde tercih edilen süreç (Creswell, 2016) takip edilmiştir. Bu nedenle öncelikli olarak araştırmacı tarafından görüşmelerin deşifresi yapılmış ardından manuel olarak kodlar oluşturulmuş ve kodların bir araya getirilmesiyle ifadelerdeki benzerlikler belirlenip üst temalara ulaşılmıştır ancak analizler sonucunda alt temalar çıkmamıştır. Veriler betimsel analiz ve içerik analizi kullanılarak çözümlenmiştir. Betimsel analizde veriler, önceden belirlenen temalar altına yerleștirilirken; içerik analizinde veriden, kodlara ait alt tema ve temalar çıkarılır (Yıldırım \& Şimşek, 2011). Strauss ve Corbin'e göre (1998) ise betimsel analizde katılımcı görüşlerinin belirgin şekilde aktarılması için doğrudan alıntılar yapılmakta, betimlemeler araştırmacı tarafından neden-sonuç ilişkisi bağlamında yorumlanmakta iken içerik analizinde ise veriler kavramsal hale getirilip düzenlenmekte ve temalaştırılmaktadır. Nitel araştırma yönteminde yer alan meslektaş teyidi (Yıldırım \& Şimşek, 2011) araştırmanın iç güvenirliği ve geçerliği için kullanılmıştır. Araştırmada hangi sorulara cevap arandığının açık bir şekilde ortaya konulması ve geçerli olmayan verilerin ayıklanması diğer iç güvenirlik 
adımlarındandır. Dış güvenirlik adımları ise katılımcıların tanıtılması, veri toplama ve analiz yöntemleriyle ilgili açıklamaların yer almasıdır.

\subsection{Araştırmanın etik izni}

Yapılan bu çalışmada "Yükseköğretim Kurumları Bilimsel Araştırma ve Yayın Etiği Yönergesi” kapsamında uyulması gerektiği belirtilen tüm kurallara uyulmuştur. Yönergenin ikinci bölümü olan "Bilimsel Araştırma ve Yayın Etiğine Aykırı Eylemler" başlığı altında belirtilen eylemlerden hiçbiri gerçekleştirilmemiştir.

\section{Etik kurul izin bilgileri}

Etik değerlendirmeyi yapan kurul adı: İstanbul Medipol Üniversitesi Sosyal Bilimler Bilimsel Araştırmalar Etik Kurulu Başkanlı̆̆

Etik değerlendirme kararının tarihi: 14/08/2020

Etik değerlendirme belgesi sayı numarası: 43037191-604.01.01-E.38098

\section{BULGULAR}

Psikolojik danışmanların yas danışmanlığına yönelik algılarını, deneyimlerini ve Türkiye'deki yas danışmanlığı uygulamalarına ilişkin değerlendirmelerini ortaya koymak amacıyla sorulan görüşme soruları ve ulaşılan temalar Tablo 2'de yer almaktadır.

\begin{tabular}{|c|c|c|c|c|}
\hline \multicolumn{5}{|c|}{$\begin{array}{l}\text { Tablo } 2 . \\
\text { Yas Danıșmanlığı Uygulamalarına İlişkin Ulaşılan Temalar }\end{array}$} \\
\hline Sorular & Tema 1 & Tema 2 & Tema 3 & Tema 4 \\
\hline $\begin{array}{l}\text { 1. Size göre 'yas' kavramı ne anlam ifade } \\
\text { ediyor? }\end{array}$ & Çok boyutlu yas & - & - & - \\
\hline $\begin{array}{l}\text { 2. Yas danışmanlığıyla ilgili ne } \\
\text { düşünüyorsunuz? }\end{array}$ & $\begin{array}{l}\text { Yas danışmanlığına iliş̧kin } \\
\text { olumsuz algı }\end{array}$ & - & - & - \\
\hline $\begin{array}{l}\text { 3. Hangi durumlarda yas danışmanlığı } \\
\text { yapıyorsunuz? }\end{array}$ & $\begin{array}{l}\text { Doğrudan başvuru ya da } \\
\text { dolaylı karşılaşma }\end{array}$ & - & - & - \\
\hline $\begin{array}{l}\text { 4. Yas vakası çıktı̆̆ında nasıl } \\
\text { çalışıyorsunuz? }\end{array}$ & Duyguya varmak & $\begin{array}{l}\text { Yasın varoluşsal } \\
\text { yerine ya da yaşantısal } \\
\text { etkisine bakmak }\end{array}$ & $\begin{array}{l}\text { Yakın hissedilen terapötik } \\
\text { yaklaşımlara göre hareket }\end{array}$ & $\begin{array}{l}\text { Çalışılan kitleye } \\
\text { göre müdahale }\end{array}$ \\
\hline $\begin{array}{l}\text { 5. Türkiye'de psikolojik danışmanların yas } \\
\text { danışmanlığına yönelik eğilimleri nedir? }\end{array}$ & Terapistin kendi yası & Varoluşsal kaygı & $\begin{array}{l}\text { Mesleki/Kişisel yetersizlik } \\
\text { algis1 }\end{array}$ & - \\
\hline $\begin{array}{l}\text { 6. Türkiye'de yasla ilgili profesyonel } \\
\text { yardım talep etme süreci size göre nasıl } \\
\text { ilerliyor? }\end{array}$ & Yasa kültürel etki & - & - & - \\
\hline $\begin{array}{l}\text { 7. Yas danışmanlığı konusunda } \\
\text { beklentileriniz neler? }\end{array}$ & $\begin{array}{l}\text { Kuramsal ve uygulamalı } \\
\text { eğitim talebi }\end{array}$ & - & - & - \\
\hline
\end{tabular}

Araştırmanın, 'Size göre yas kavramı ne anlam ifade ediyor?' sorusundan elde edilen bulgu çok boyutlu yas teması altında toplanmıştır. Sadece bir katılımcı, 'Kayıp, ölüm...' yorumunu yaparken diğer katılımcılar ölüm, boşanma, ayrılık, mekân kaybı, iş kaybı, kimlik/çocukluk/gençlik kaybı gibi kayıpların olduğu durumlardan sonra yasın ortaya çıkabildiğini belirtmiştir. Bazı katılımcılar yasla birlikte çekilen acıyı vurgulamıştır.

'Yas deyince sadece ölüm gibi bir kavram düşünmüyorum. İşten ayrlmak da sevgiliden ayrllmak da boşanmak, ilk defa aileden ayrılmak gibi birçok şey yas sürecine dahil edilebilir. Her birini kayıp sonrası yas gibi değil de her birinin içerde bir yeri var ve o çıktı̆̆ zaman onun da bir yası tutuluyor.' (K-8)

Araştırmanın, 'Yas danışmanlığı yapıyor musunuz?' sorusuna katılımcıların bir kısmı yasla çalıştı̆ııı (bazı katılımcıların yas danışmanlığ katılımcılar ise yas vakası çıktıkça (birkaç kez) yas danışmanlığı yaptığını belirtmiştir.

'Aslında her seans bir kayıp, yas üzerine. (...) Çoğu seansta ölüm süreci konuşuluyor. Kaybedilmiş bir ebeveyn ya da kaybedilmiş bir dostluk oluyor. Ölüm anlamında şu anda çalıştı̆̆ım bir vaka var. Yedi aydır geliyor bana. Annesini bundan üç sene önce kaybetmiş ama yasın yeni yaşıyor ve bu yas süreci yeni ortaya çıkıyor ve çocuk fikri ortaya çıktkktan sonra kendi annesiyle ilgili kaybı hissetmeye başladı. Çünkü kendisi de anne olmaya başladı̆̆ andan itibaren kendisini de kaybetmek, ölüm korkusuyla geldi. Aslinda bu ölüm korkusundan ziyade annesini kaybetme korkusunu, annesini kaybetme duyguların yaşamama hali ve şu anda yaşamaya başladı.' (K-1)

Bazı katılımcıların soruda yer alan yas danışmanlığı kavramından rahatsız oldukları düşüncesiyle araştırmacı tarafindan yöneltilen, 'Yas danışmanlığıyla ilgili ne düşünüyorsunuz?' sorusundan yas danışmanlığına ilişskin olumsuz algı teması elde edilmiştir. Tüm katılımcılar terapötik süreçte yasla çalışmanın önemli olduğunu 
vurgularken bazı katılımcılar yas danışmanlığı kavramına, danı̧̧manlık hizmetini daraltabileceğinden karşı çıkmıştır. Diğer gerekçeler arasında, bu kavramın danışanı algılayışı belirlemesi (örn. yas tutan Ayşe), yas konusunda uzmanlaşılmasının yası travmatik olarak algılatma ihtimali, yaşamın her alanında kayıp olduğu için ayrı bir çalışma alanı olarak yansıtılmaması gerekliliği, farklı ekollerin ve eğitimlerin türemesini (örn. boşanma terapisi, yas danışmanlığı eğitimi) ticari görme, bireysel deneyimleri görmezden gelmeye yol açabileceğinden yapılandırılmış yas danışmanlığını yanlış bulma yer almaktadır.

'Yas danışmanlığı diye insanlar bir şeyler yazıyor. OKB danışmanlığı o zaman işte, öfke danışmanlı̆̆ı o zaman ya da işte ne bileyim taciz danışmanlığı. Şimdi bu, insanların yaşadılkları travmalar. Yas da bir travma aslinda. Evet, özel tarafları olan bir süreç ama çok da varoluşsal bir tarafi da var. Ölümün anlamı, anlamlandırma, hayattaki yeri. Hani bunun böyle, bu ayrışstııllyor ya orasını birazcık psikopolitik buluyorum (alaycı bir şekilde güldü, gergin bir şekilde konuştu). Yani hani böyle bir şey var, yas danışmanlı̆̆ da var, bunun da eğitimi böyle böyle olmall. Ama başka bir travmanin... Travmayı da ele aldı̆̆ınız zaman 'deprem danışmanlı̆̆ı' yok mesela. Onun için (alaycı bir şekilde güldü) ...' (K-7)

Araştırmanın, 'Hangi durumlarda yas danışmanlı̆̆ı yapıyorsunuz/yasla çalışıyorsunuz?' sorusundan (yas danışmanlığı kavramından rahatsız olan katılımcılara hangi durumlarda yasla çalıştıkları sorulmuştur) elde edilen bulgu doğrudan başvuru ya da dolaylı karşılaşma teması altında toplanmıştır. Katılımcıların çoğu doğrudan yasla ilgili terapiye başvurunun çok az olduğunu ya da hiç olmadığını ancak başka bir konuyla gelinip (örn. depresyon, kaygı) terapötik süreçte bastırılan ya da yaşanmayan/ertelenmiş yasın ortaya çıktığını belirtmiştir. Bu katılımcıların bir kısmı, aynı zamanda okulda çalıştıkları için bu ortamda kayıplarla karşılaşmanın kaçınılmaz olduğunu (örn. ebeveynlerin boşanması, ebeveyn ölümü, arkadaş ölümü) ve yasla çalışmak zorunda kaldıklarını belirtmiştir.

'Aile içinde yas, yaşanmamış yas, ertelenmiş yaslarla karşılaşıyorum. İlla yas yaşatmalıyız gibi değil ama orada olanın ne olduğuna dair konuşmamız gerekebiliyor. Bazen yas sebebiyle direk başvuru oluyor. Yani bizim açmayıp danışanın gündemle geldiği. Orada eşlik ediciliğimizle, süreç içinde nasıl yardım edeceğimizle ilgili...' (K-2)

'Boşanmayı da kapsayan, ebeveyn kayıplarını kapsayan, ani hastalıklarla olan çok yakın sevdiği kişileri kaybeden çocuklarımız oluyor okullarda. Anne-baba kaybl, anne-baba ayrllğ̆l, ögretmen kaybl, arkadaş kaybl, sevdiği herkesin kaybı aslında çocuklar için bir yas sürecini getiriyor ve bu süreçte çocuklara danışmanlık yaparak onlara eşlik ediyoruz.' (K-5)

Araştırmanın, 'Yas vakası çıktı̆̆ında nasıl çalışıyorsunuz?' sorusundan elde edilen bulgular, duyguya varmak; yasın varoluşsal yerine ya da yaşantısal etkisine bakmak; yakın hissedilen terapötik yaklaşımlara göre hareket ve çalışılan kitleye göre müdahale temaları altında toplanmıştır. Katılımcıların çoğu, güvenilir bir terapötik ortam içerisinde yaşanılan kayıpla ilgili çoğu zaman bastırılmış, yüzleşmekten çekinilen duygulara ulaşmak ve bunların sağlıklı bir şekilde yaşanması için çalıştığını ve bu anlamda bazı katılımcılar duygu boşalımının sağlanması için göz hareketleriyle duyarsızlaştırma ve yeniden işleme (EMDR) tekniğini kullandığını; katılımcıların bir kısmı yaşanılan kaybın bireyin varoluşunda ne anlam ifade ettiğini, yaşantılarına etkilerinin neler olduğunu araştırdıklarını; tüm katılımcılar tercih ettikleri terapötik yaklaşımların (örn. analitik, sistemik, varoluşçu, bilişsel davranışçı, EMDR) yöntem ve tekniklerinden örnekler vererek (yeniden çerçeveleme; zihinsel yapılanmayı sağlama; serbest çağrışım; rüyaların, aktarımların yorumlanması; sosyal davranış ödevleri; EMDR'nin travmayla ilişkili testlerini uygulama) yas vakalarıyla nasıl çalıştığını; bazı katılımcılar da çocuklarla farklı yetişkinlerle farklı çalıştı̆̆ını, çocuklarla yapılan çalışmalarda, bireysel olarak kendini ifade etme konusunda çocuklar güçlük yaşadığı için aileden bilgi alındığını, sanatsal etkinlikler uygulandığını (örn. resim çizdirme, kum tepsisi etkinliği), test ve envanterlerden yararlanıldığını belirtmiştir.

'Başta danışman daha dinleyen ve orada olan... Çok aktif olmamall. Çok az yeniden çerçevelemeleri ya da yeniden zihinsel yapılandırmaları ikinci aşamada yavaş yavaș... Belki ondan sonra geçmişin geçmiş olması üçüncü aşama ve artık yeni bağları da kurabilmesine, geçmesine eşlik etmek, yardımcı olabilmek. Ama bu danışanı asla zorlamak olmamall.' (K-2)

'Anlatmasını sağladım. Duygusunu ifade etmesini sağladım. O adamı, orada nerelere girdiğini ona gösterdim. Hani bazen yorumlama da yaptım. Hazır olduğunu hissettiğimde...' (K-8)

'Belli bir doğuștan gelen beyinsel yatkinlı ya da yapı var. Bu insanlar yastan diğerlerinden daha fazla etkilenebiliyor. Şimdi bu doğuştan yatkınlık psikoterapistlerin, pedagogların ya da psikologların kolay müdahale edebilecekleri bir şey değil. Onların çalıştıkları alan o olay dediğimiz şey. Olayı algılama biçimleri. O algılama biçimini işte diyelim bilişsel davranışçı terapi ile diyelim şema terapiyle diyelim EMDR ile biraz daha hafifletmeye ya da esnetmeye çallşlyorlar. Ama burada en önemli şey karşıldaki kişinin size güvenmesi.' (K-6)

'O kadar başka ki kişsilerin yaşadığı deneyimler. Örneğin, bir danışanımın yas sürecinde, baba rolü üstlenmesi gerektiğine dair yaşantısı olabiliyor eğer babasını kaybetmişse ve dolaylsıyla bu yaşantı şekli o kişinin gündelik ilişkileriyle alakalı bir probleme dönüşebiliyor. O yas, yasın kişide oluşturduğu şey, o kişiye özgü. Niç̧in o kişide 
o özellik çıkmaya başllyor? Standart bir yas tepkisi olduğunu ben düşünmüyorum açıkçası. Belki üzüntü diyebiliriz ama gerçekten üzüntü de olmayabiliyor. Dolaylsıyla o kişide bu tam olarak ne anlama geliyor, bu kişi bu rolü benimsediğinde neleri yaşlyor? Buna dair ayrintıll incelemeler yapıyoruz terapi sürecinde. Gerçekten bu kişi o sorunu, bu süreci nasıl yaşıyor?' (K-10)

Araştırmanın, 'Türkiye'de psikolojik danışmanların yas danışmanlığına yönelik eğilimleri nedir?' sorusuna yönelik görüşleri terapistin kendi yası, varoluşsal kaygı ve mesleki/kişisel yetersizlik algısı temaları altında toplanmıştır. Katılımcıların bir kısmı psikolojik danışmanların ertelenmiş yaslarıyla yüzleşmekten kaçındıkları için yasla çalışma konusunda isteksiz olduklarını ve bu katılımcıların üçü kendi yasıyla yüzleşip, çözüm sürecinde yer aldığı için yasla çalş̧ma konusunda kendilerine güvendiklerini ve konuya ilgi duyduklarını belirtmiştir. Varoluşsal kaygı temasında bazı katılımcılar yasla çalışmanın kişinin kendi ölümüyle yüzleşmesine neden olabileceğinden korkulan, kaçınılan bir konu olduğunu; mesleki/kişisel yetersizlik algısı temasında ise çoğu katılımcı psikolojik danışmanların üniversitede konuyla ilgili iyi bir eğitim almamaları nedeniyle bilgi, beceri ve deneyim eksikliği yaşadıklarını dolayısıyla yasla çalışmak istemediklerini ve konuyla ilgili yetkin buldukları uzmanlara yönlendirmenin yapıldığını belirtmiştir.

'Kaçıyorlar. Yaslarını çalışmadıkları için zor bir şey. Ölümle ilgili konuşmak, ölümü konuşmak acı verici. Bir insan ölümü konuşmaya başladığında, kendi çocuğunun ölümünü, kendi ölümünü, annesinin ölümünü, akrabalarının ölümünü konuşmak da oluyor. Bir insan başkasının ölümünü konuşuyorsa, kendi ölümü̈le ilgili yüzleşmelere başlaması lazım. Varoluşsal meseleleri ortaya çıkıyor. Bir insan varoluşsal meselelere gelmemişse zaten terapist olma kimliği de zaylf olarak düşünüyorum.' (K-1)

'Bence birç̧ok psikolojik danışman kendi yas süreçlerini çözümlememiş̧lerdir. Kendileri bir kere sağllklı bir şekilde kendi yaslarının üzerinde durmamışlardır. Ben de dedim ya çok uzun yıllar sonra kendi çok önemli bir kaybımın, gerçekten hala yas sürecinde olduğumu, ertelenmiş bir yasımın olduğunu fark ettim (katılımc1, önceki açıklamalarda üniversitede konuyla ilgili aldığı derste farkındalığının arttığını belirtmişti). Biraz da oradan bu işin yapılabilirliğini kendi açımdan uygun buldum, kendi sürecimle yüzleştikten sonra.' (K-4)

Katılımcıların, Türkiye'de yasla ilgili profesyonel yardım sürecinin nasıl olduğuna yönelik görüşlerinden elde edilen bulgu yasa kültürrel etki teması altında toplanmıştır. Çoğu katılımcı yas sürecindeki bireylerin yaşadığı acıyı kendi içinde halletmeye çalıştığını, yardım isteme konusunda gönülsüz olduğunu belirtmiştir. Bu durumun ortaya çıkmasında, toplumun, kayıptan belli bir süre sonra kayıp yaşayan kişilerin duruma alışmasını beklemesi; dini inancı nedeniyle kaybı kabullenme gerekliliği; zamanın çekilen acıyı dindireceğine ilişkin toplumsal algı; duyguların bastırıldığı/üzerinin örtüldüğü bir toplumda yaşamanın etkisi gibi nedenler bazı katılımcılar tarafindan ifade edilmiştir. İki katılımcı, bazı yörelerde yas sürecinin daha sağlıklı yürütüldüğünü, bazı yörelerde ise bireyselliğin ön planda olması ve sosyal destek alanlarının azlığı nedeniyle kendi duygularını paylaşacak destek kaynakları bulamadığını belirtmiştir.

'Mesela kaybın üzerinden 10 sene geçmiş, dört sene geçmiş. Danışan bununla ilgili destek almayı belki sağllklı bulmuyor. Sağllklı derken şunu kastediyorum. Artık benim bunu atlatmış olmam gerekirdi. Çünkü etrafindakilerin onunla ilgili söylediği de o.' (K-8)

'Bazı yörelerde televizyon açılmaması, yemeklerin yenilmemesi, sakalların kesilmemesi, o odaya girilmemesi, eşyalara dokunulmaması, bunlar hepsi aslında ölümün konuşulmasının zor olduğu ve yüzleşmenin zor olduğu bir şey. (...) Bizde iki duygu konuşulmuyor. Ölüm ve cinselliğin konuşulması çok yasak bir şey.' (...) Kültürel olarak bunları çok defa yaşadım. Yas evlerine gittim. Bazen gülme reaksiyonları, espriler... Bastırma o kadar net ki, kimse o yası yaşayanı dinleyemiyor. Çünkü kendi yasına gidiyor, o acısına gidiyor ve bu zor bir şey. Ateş o anda kendi yüreğine değiyor, onun yüreğinden çıkarmak için uğraşıyor.' (K-1)

'Bizim toplumun belli bir kültürü, inançları da var. Bununla da ilgili, ölümü kabullenmemek olmaz gibi. Ölümle ilgili konuşuruz ama bir korku sonuçta. Bir de biz duygularını çok fazla yaşayan bir toplum değiliz.' (K-9)

Katılımcıların yas danışmanlığı konusundaki beklentileri kuramsal ve uygulamalı eğitim talebi teması altında toplanmıştır. Çoğu katılımcı psikolojik danışman adaylarının kayıp ve yas süreciyle ilgili bilgi ve becerilerinin arttrrılması için üniversite eğitiminde teori ve uygulamaya yönelik işlevsel bir dersin olması; kapsamlı atölye çalışmalarının yapılması; sempozyum ve kongrelerin düzenlenmesi; bilimsel yayınların arttırılması gerekliliğini vurgulamıștır. Sadece bir katılımcının yasla ilgili teori ya da yapılandırılmış programlar geliştirilmesine karşı olması; bireysel deneyimleri göz ardı eden genelleştirilmiş bilgilerin verildiği bir ders yerine vaka çalışmalarına ağırlık verilen kitapların olmasının daha faydalı olacağını belirtmesi dikkat çekmiştir.

'Bir ders olarak algılanması... Çünkü insanların en çok üzerinde acı çektiği, en çok canlarının yandı̆̆l, kaybetme olgusudur ve bir nesnenin kaybedilişi, bunun kabullenişi çok zordur. Ve buna hazırllkl olmayan psikoterapistler, psikolojik danışmanlar, psikologlar gerçekten o odada sağllklı terapi yapamıyorlar. Çünkü kendi yasları o kadar çalışılmamış halde oluyor ki, karşısındaki danışanın yasını algılamak zor geliyor. Onun için psikoterapist, psikolog, psikiyatristlerin bu konuda ders alması ve kendi yas sürecini çalışması gerektiğini düşünüyorum.' (K-1) 
'Yas terapisinin ortaya çımasının çok sağlıklı olduğunu düşünmüyorum. Çünkü burada yasta kişinin travmatize olmasını etkileyen şey onun zaten önceki yaşantısı, dinamikleri, onun dünyayl, evreni, kaybettiği nesneyi, kişiyi algılayışı. Bunlar önemli bence yasta. O yüzden genel terapi yaklaşımlarının içerisine yas başlı̆̆ı eklenebilir sadece. Peki yasta bu nasıl uygulanabilir şeklinde... Üniversitelerde derslerde, bir terapi ekolü allyorsan onun içerisinde bir modül olabilir.' (K-3)

'Illkokulda görev yaptım. Eğitim kurumlarında... Birçok psikolojik danışmanla aynı ortamda vaka çalışma imkânım oldu ve bu süreçte beceri eksikliklerinin olduğunu çok net gördüm. Kendi açımdan öyle meslektaşlarım açısından da. İsteğim şu olabilir. Belki bu konuda biz uzmanların becerilerini arttıracak beceri eğitimleri, tecrübelerinin arttırlacă̆ vaka çalışmalarının biraz daha sahadaki eğitimlere, uygulama alanlarına yaygınlaştıılmasını çok isterim.' (K-5)

\section{TARTIŞMA ve SONUÇ}

\subsection{Tartış̧ma}

Yas, yaşanılan kaybın ardından verilen fiziksel, davranışsal, ruhsal ve duygusal yoğun tepkileri içeren süreçtir. Yaşam içinde kayıplar kaçınılmaz olmakla birlikte, en somut ve geri dönüşü olmayan kayıp ölümdür. Ölüm, bireylerin hayatında yaşayabileceği ve karşılaşabileceği en somut kayıptır. Hayatın içindeki her kaybın yeniden doğuşa dönüştürülmesinin ve yeniden yapılandırılmasının mümkün olabileceği düşünülmektedir. Bireyler, sevdikleri bir kişinin ölümünün ardından, soyut bağlamda, kaybettiği ilişki bağını anlamak ve yeniden yapılandırmak üzere kendisini dinamik bir sürece bırakır. Yas süreci, sevilen birinin ardından her bireyin kendi içselliğinde tecrübe edeceği çok özel bir süreçtir (Genlik, 2012).

Araştırmada yasın anlamına ilişkin soruya katılımcıların farklı kayıp türleri üzerinden cevap verdikleri görülmektedir. Katılımcıların cevaplarında, kaybı sadece ölümle ilişkilendirmedikleri dikkat çekmektedir. Yası, kayıp sonrası ortaya çıkan bir durum olarak nitelendiren katılımcıların, ölüm, boşanma, ayrılık, mekân kaybı, iş kaybı, kimlik/çocukluk/gençlik kaybı vb. farklı kayıp türlerine bağlı olarak, yaşanan acı ile ilişkilendirdikleri ve örnekler yoluyla açıkladıkları görülmüştür. İnsanlar yaşamlarında kaçınılmaz olarak bazı kayıplarla yüzleşmektedir. Bu kayıplar sevilen birinin ölümü olabileceği gibi, boşanma, iş kaybı, güven kaybı, ilişki kaybı, sağlık kaybı, ekonomik kayıp gibi farklı kayıp türlerini de içerebilir (Walsh \& McGoldrick, 1991). Yaşanan tüm bu kayıplar bireylerin yaşamını kaybın öncesi ve sonrası olarak isimlendirilebilecek şekilde değiştirebilir (Apaydın, 2017).

Katılımcıların yas danışmanlığı yapıp yapmamalarına ilişkin yanıtlarında, bazı katılımcıların yas danışmanlı̆̆ ifadesi yerine yasla çalışmak ifadesini kullanmaları dikkati çekmektedir. Bu ifadeye vurgu yapan katılımcılar, yas danışmanlığı ifadesini sınırlandırıcı bulduklarını söylemişlerdir. Özellikle 'ölüm yoluyla kayıp' üzerinde danışan görmediklerini ve yasla çalışmadıklarını, bununla birlikte terapötik süreçte yasla çalışmanın karşılaşılabilecek bir durum olduğunu vurgulamışlardır. Katılımcılar, farklı gerekçelerle terapötik sürece başvuran danışanların, geçmişte yaşadıkları kayıplara bağlı olarak yaslarının danışma sürecinde ortaya çıkabildiğini ifade etmişlerdir.

Her kayıp yaşayan bireyin yas danışmanlığına ihtiyacı olmadığı ancak yasın hem bireysel hem de sosyal bir deneyim olması nedeniyle yas danışmanlığı sürecinin kişiye özgü olarak oluşturulması gerektiği literatürde dikkati çekmektedir (Külahçıŏlu, 2017). Normal yas dışında özellikle travmatik yas ve karmaşık/patolojik yas türlerinde profesyonel anlamda yasla çalışılması gerekmektedir. Worden (2018) yas danışmanlığını, kaybedilen kişi olmaksızın yeni yaşama uyum sağlama ve sağlıklı baş etme konusunda kişiye dönük sunulan profesyonel yardım olarak ele almaktadır.

Yas danışmanlığına olumsuz yaklaşıldığını gösteren açıklamaları yapan katılımcılar, yas konusunda uzmanlaşılmasının yası travmatik olarak algılatma ihtimaline, yaşamın her alanında kayıp olduğu için ayrı bir çalışma alanı olarak yansıtılmaması gerektiğgine, farklı ekollerin ve eğitimlerin türemesini ticari gördüklerine, bireysel deneyimleri görmezden gelmeye yol açabileceğinden yapılandırılmış yas danışmanlığını yanlış bulduklarına vurgu yapmışlardır. Literatür incelendiğinde, yas, yas süreci ve yas danışmanlığını konu edinmiş birçok kuram ve model görülmektedir. Ölüm ve sonrası yas sürecindeki evrelerle ilgili Freud, Lindemann, KüblerRoss, Rando, Bowlby, Worden gibi kuramcılar açıklamalar sunmuştur. Özellikle terapötik bağlamda uygulamalı yaklaşımlar geliştiren Worden'ın çalışmaları literatüre yön vermiştir (Şenelmiş, 2006). Erken dönem çalışmalar yası evrensel bir olgu olarak ele alırken yakın dönem çalışmalar ise yası bireysel, sosyal, kültürel etmenlerle birlikte ele almaktadır (Apaydın, 2017). Yas danışmanlığında birçok kuram ve model içerisinde profesyonellerin sıklıkla, EMDR terapisi, öyküsel terapi, kararlılık ve kabul terapisi, duygu odaklı terapi, bilişsel davranış̧ı terapiyi kullandıkları görülmektedir (Kurşuncu, 2017; Külahçığlu, 2017).

Katılımcılar yanıtlarında, doğrudan yasla ilgili gelen başvurunun çok az olduğunu ya da hiç olmadığını ancak farklı bir konuyla gelinip (örn. depresyon, kaygı) terapötik süreçte bastırılan ya da yaşanmayan/ertelenmiş yasın ortaya çıktığını belirtmiştir. Kaçınılmaz olarak çalışılan her alanda psikolojik danışmanların karşısına yasla ilgili 
durumların çıktığı araştırmada ifade edilmiştir. Profesyonel yardım süreci olarak yas danışmanlığı bireysel veya grup danışmanlığı olarak gerçekleştirilebileceği gibi (Külahçıŏlu, 2017) çift/aile danışmanlığı içerisinde de yas tepkileri ve baş etme üzerinden çalışılabilmektedir (Worden, 2018).

Yas vakası çıktığında nasıl çalıştıklarına ilişkin açıklamalarında katılımcılar danışanlarının duygularını ifade etmelerini, açığa çıkarmalarını, fark etmelerini sağladıklarını, yasın yaşantısal etkisine baktıklarını, kendilerini yetkin hissettikleri terapötik yaklaşımlara ve tekniklere başvurduklarını ve danışanlarının gelişimsel özelliklerine göre müdahale ettiklerini belirtmişlerdir. Doğal seyri içerisinde kayıp sonrası yeni duruma uyum sağlamayı gerektiren normal yas sürecinde müdahaleye gerek duyulmamaktadır (Şenelmiş, 2006) ancak kronikleşmiş, uzamış, maskelenmiş veya travmaya maruz kalarak yaşanan yas sürecinde profesyonel yardım gereklidir. KüblerRoss'a göre yas ancak ölenin ölümlülüğünün kabulü ile tamamlanacak bir süreçtir (Genlik, 2012). Farklı modellerin özünde, yasla çalış1lırken ilk vurgulanan nokta bireyin yas gerçeğini kabul edebilmesi ve kayba ilişkin duygularını açığa çıkarması, ifade edebilmesi ve farkına varabilmesidir (Worden, 2008).

Türkiye'de psikolojik danışmanların yas danışmanlığına yönelik eğilimlerinin neler olduğuna bakıldığında katılımcılar, psikolojik danışmanların kendi ertelenmiş yaslarıyla, ölüm korkularıyla yüzleşmekten kaçındıkları ve konuyla ilgili bilgi, beceri, deneyim eksikliği yaşadıkları için yasla çalışma konusunda isteksiz olduklarını belirtmiştir. Katılımcıların, Türkiye'de yas danışmanlığına ilişkin çalışma eğilimlerini açıklarken kendi kişisel yaşantıları, tercihleri ve özellikleri üzerinden cevaplandırdıkları görülmektedir.

Stroebe ve Schut (1999), yası evrensel, yas sürecini ise bireysel bir durum olarak görmektedir. Kayıp sonrasında duygusal, davranışsal, fiziksel ve sosyal olarak ortaya çıkan zorlu baş etme durumunda bireylerin sadece kaybedilen kişi ile ilgili değil kendileri ile ilgili gerçekliği de ele aldıkları düşünülebilir. Varoluşsal bir durum olarak ölüm, sadece sevilen kişinin kaybını değil aynı zamanda kişinin kendi ölümlülüğüyle de yüzleşmesini zorunlu kılmaktadır (Yalom, 1999). Frankl (1996), ölümün biyolojik olarak bir yaşamı sonlandırmakla birlikte kaybedilen ilişkiyi sonlandırmayacağını, yaşam bütünlüğü içerisinde kişinin varoluşunu etkileyeceğini ve geçmişinde varlığını sürdüreceğini belirtmiştir. Profesyonel çalışanlar olarak psikolojik danışmanların kendi geçmiş kayıpları, bitmemiş işleri, yasla çalışma sürecinde onları zorlayan durumlar olarak karşılarına çıkabilir.

Tükenmişlik ve empati yorgunluğunun psikolojik danışmanlarda görülme olasıllğı bulunmaktadır (Stebnicki, 2007; Wardle \& Mayorga, 2016; Zhang vd., 2020). Bu noktada hem kişisel hem de mesleki olarak danışmanların iyi oluşları ve duygusal öz bakım becerilerine sahip olmaları önemlidir. Psikolojik danışmanların kendi yas süreçlerinin farkında olması, sağlıklı biçimde yas süreçlerini tamamlamış olması danışanlarına dönük hizmeti sağlıklı biçimde verebilmelerinde temel bir zorunluluk olarak düşünülmektedir. Danışmanların kendilerini tükenmişliğe götürecek uyarılara dikkat etmesi, öz-bakım becerilerini ve iyi oluşlarını desteklemesi ve gerektiğinde süpervizyon desteği ile çalı̧smalarını sürdürmesi hem mesleki hem de bireysel anlamda koruyucu ve destekleyici olmaktadır (Padır \& Erdur-Baker, 2017).

Türkiye'de yasla ilgili danışanların profesyonel yardım isteme sürecinin nasıl olduğuna yönelik katılımcı görüşlerinde, yasa kültürel etkinin dikkat çektiği tespit edilmiş̧ir. Çoğu katılımcı yas sürecindeki bireylerin yaşadığı acıyı kendi içinde halletmeye çalıştığını, yardım isteme konusunda gönülsüz olduğunu belirtmiş̧tir. $\mathrm{Bu}$ durumun ortaya çıkmasında, toplumun kayıptan belli bir süre sonra kayıp yaşayan kişilerin duruma alşsmasını beklemesi, dini inancı nedeniyle kaybı kabullenme gerekliliği, zamanın çekilen acıyı dindireceğine ilişkin toplumsal algı, duyguların bastırıldığı bir toplumda yaşamanın etkisi gibi nedenler bazı katılımcılar tarafindan ifade edilmiştir.

Sosyo-kültürel faktörler yasın nasıl yaşanacağını belirleyen unsurlar arasında görülmektedir (Bildik, 2013). Kültürel normlar içinde kabul edilen ve desteklenen davranışlar, inançlar, manevi değerler, alı̧skanlıklar kayıp gerçeğinin kabulü, yas tepkilerinin belirlenmesi, yas sürecinin sağlıklı biçimde tamamlanmasında dikkati çekmektedir. Sosyal destek ve yakın çevrenin yaklaşııı bu sürece etki eden unsurlar arasındadır (Apaydın, 2017). Kayba bağlı tepkileri değerlendirirken kültürün daha fazla vurgulandığı, günümüz çalışmalarından önce yasla ilgili öne sürülen kuramların genellikle yasın çözümlenmesi ile sonuçlanan aşamalardan meydana geldiği ve bu kuramlarda 'yasın çözümlenmesinin' amaçlandığı dikkat çekmektedir (Bağcaz, 2017). Kayıp yaşayan kişinin, aile ya da çevresinde bir sosyal destek ağının olması, kişinin yas sürecini ve kayba yönelik uyumunu önemli derecede etkilemektedir. Sosyal desteğin varlığı kadar, yas tutan kişinin algıladığı desteğin derecesi de büyük önem arz etmektedir (Gizir, 2006). Yasla çalışırken, danışanın kaynaklarının değerlendirildiği aşamada, danışanın özyeterliliği, başa çıkma becerileri kadar danışanın sosyal destek mekanizmasına ne düzeyde sahip olduğu, yakın çevrenin ve kültürün yas sürecindeki bireye yaklaşımı önemli bir nokta olarak görülmektedir (Külahçığlu, 2017). Sosyal desteğin doğrudan etkisi olmamakla birlikte aracı rolü olduğu ve kayıp yaşayan bireyler üzerinde koruyucu bir role sahip olduğunu gösteren araştırma bulguları da mevcuttur (Koyuncu, 2015).

Katılımcıların, yas danışmanlığı konusundaki beklentilerinde kuramsal ve uygulamalı eğitim talebinin olduğu görülmektedir. Psikolojik danışman adaylarının kayıp ve yas süreciyle ilgili bilgi ve becerilerinin arttırılması için üniversite eğitimleri sırasında hem kuram hem de uygulamaya yönelik eğitim almalarının önemi; kapsamlı atölye 
çalışmalarının yapılması; sempozyum/kongreler düzenlenmesi; bilimsel yayınların arttırılması gerekliliği vurgulanmıştır. Psikolojik danışmanların aldıkları eğitimle birlikte yas yaşantısıyla başa çıkacak temel becerilere sahip oldukları ve kendi kayıplarına karşın etkin bir yas tecrübesi geçirmiş oldukları varsayılsa da psikolojik danışma faaliyetleri çerçevesinde tükenmişlik yaşama riskleri bulunmaktadır. Dolayısıyla, psikolojik danışmanların kişisel sınırlılıklarının farkında olarak, belirli bir zaman aralı̆ı̆ında yas kaynaklı danışan sayısını sınırlamaları ve kendi ihtiyaçları doğrultusunda gerekli yardımları alabilecek destek kaynakları oluşturmaları önerilmektedir (Gizir, 2006).

Yas, özel bir başlık olmakla birlikte psikolojik danışmanların çalıştıkları farklı grup ve sorun alanlarında karşılaşabilecekleri bir olgudur. Yasla çalışmak, yöntem ve teknikleri itibariyle özelinde yas ve yas sürecini, vak'a formülasyonunu yapabilmede bilgi, beceri ve yeterliliği gerektirmektedir. Gerek lisans eğitimi sırasında gerekse sonrasında yasla çalışmaya ilişkin verilecek kuramsal ve uygulamalı eğitimlerin danışmanların mesleki yeterliliklerini kazanmalarına önemli katkı sağlayacağı düşünülmektedir.

Bandura'ya göre (1986), bireyler, genellikle, ne yapmaları gerektiğini bilseler de uygun davranışı sergilemeyebilirler. Çünkü kendileriyle ilişkili yetkinlik inancı fikri, bilgi ve davranış arasında bir köprü görevi görmektedir. Bu durum yetkinlik inancının bireyin davranışını ve davranışa yönelimini etkileyen önemli bir etken olmasından kaynaklanmaktadır. Gündüz ve Çelikkaleli (2009) araştırmaları sonucunda, psikolojik danışmanların kendilerini yetkin hissetmelerindeki en önemli faktörün deneyimler olduğunu ve eğitim-öğretim sürecinde uygulamalara ve süpervizyona gerekli önemin verilmesi gerektiğini ifade etmektedir. Bodenhorn ve Skaggs'e göre (2005) öz-yeterlik kavramı psikolojik danışmanların hem eğitimlerini hem de meslek hayatlarındaki performanslarını etkilemektedir. Larson vd.ne göre (1992) de eğitim gören psikolojik danışmanların özyeterlikleri, uygulama yaparken ve süpervizyon alırken gösterdikleri devamllıktan ve sergiledikleri çabadan etkilenmektedir.

\subsection{Sonuç}

$\mathrm{Bu}$ araştırma psikolojik danışmanların yas danışmanlığına yönelik algılarını, deneyimlerini ve Türkiye'deki uygulamalara ilişkin değerlendirmelerini ortaya koymak amacıyla gerçekleştirilmiştir. Araştırma sonuçlarına göre, katılımcıların yas vakalarını, mesleki süreçte her an farklı başıklarda karşılarına çıkabilecek bir durum olarak gördükleri; yasın sadece ölümle ilişkilendirilmediği, farklı kayıp türleriyle birlikte ele alındığı; yas danışmanlı̆̆ı kavramının profesyonel yardım sürecini sınırlandırdığı gerekçesiyle bazı katılımcılar tarafından 'yasla çalışmak' ifadesinin tercih edildiği; çalışılan konuların altında gecikmiş, ertelenmiş yasın çıkabildiği ve katılımcıların kendilerine yakın buldukları kuramsal yaklaşım ve teknikleri kullanmayı tercih ettikleri ortaya konmuştur. Ayrıca, yas danışmanlığına ilişkin kişisel atıfları, geçmiş deneyimleri ve yetkinlikleri üzerinden varoluşsal açıklama getirdikleri, yas sürecini kültürel ve toplumsal faktörlerle nitelendirdikleri, mesleki açıdan lisans döneminde aldıkları eğitimi yasla çalışıken yeterli bulmadıkları, kuramsal ve uygulamalı derslere ve eğitimlere ağırlık verilmesi gerekliliğini vurguladıkları görülmüştür. Yasla çalş̧an psikolojik danışmanların mesleki ve kişisel gelişimleri bağlamında, kendi varoluşlarını ve yasla ilişkilerini, geçmiş yas deneyimlerini gözden geçirmeleri, süpervizyon desteği almaları; bununla birlikte lisans eğitiminde kuramsal ve uygulamalı eğitimlere ağırlık verilmesi bu araştırma bulgularına göre önerilmektedir. Bazı katılımcıların yas danışmanlığı kavramına gösterdikleri olumsuz tepkiyle, terapötik anlamda kayıp ve yas konusuna daha derin bir perspektiften bakılması gerektiği düşünülmüş olup gerek alan bilgisi gerek terapötik süreçte yaşanılan deneyim zenginliğiyle verilen bu tepkinin akademisyenler ve ruh sağlığı uzmanları tarafından dikkate alınarak konuyla ilgili sınırlandırıcı olmayan bir söylem geliştirmeleri önerilmektedir. Bu araştırmada yer alan katılımcıların lisansüstü eğitim ve/veya farklı terapötik yaklaşımlarla ilgili uzun süreli özel eğitimler almaları aynı zamanda aktif bir biçimde danışan görmeleri nedeniyle konuyla ilgili üst düzey farkındalıkla açıklama yaptıkları görülmüştür. Dolayısıyla verilen yanıtların Türkiye'deki çoğu psikolojik danışmanın konuyla ilgili vereceği tepkileri ne derece yansıtabileceği tartışlabilir. Araştırmanın bu sınırlılığı nedeniyle lisans mezunu ve sadece okullarda çalışan psikolojik danışmanların da konuyla ilgili algılarının, deneyimlerinin, Türkiye'deki uygulamalara ilişkin değerlendirmelerinin araştıılması ve ortaya konulacak gerekliliklere yönelik teorik ve uygulamaya dönük çalışmalar planlanması önerilmektedir. Bu anlamda yapılacak çalışmalarla, özellikle okullarda çalışan psikolojik danışmanların, her an karşılaşabilecekleri yas vakalarıyla nasıl çalı̧ıllacağı konusunda farkındalıklarının artacağı düşünülmektedir. İlgili literatür incelendiğinde, ebeveyni ölen çocuklar arasında yas süresinin değiştiğine (Pickhard, 1996) ve ebeveyn ölümünün çocuklar üzerindeki duygusal, sosyal, bilişsel ve davranışsal etkilerine yönelik araştırma sonuçları (Dowdney, 2000; Elizur \& Kaffman, 1983; Furman, 1983; Noppe, 2004; Raveis vd., 1998; Worden, 1996; Y1ld1z, 2017) yapılacak çalışmaların önemini ortaya koymaktadır. Bu araştırma, nitel araştırma yöntemine göre psikolojik danışmanların yas danışmanlığına ilişkin fenomenlerinin belirlenmesi ile de sınırlıdır. 


\section{KAYNAKÇA}

Apaydın, S. (2017). Kayıp ve yas. Ö. Erdur-Baker \& İ. Aksöz-Efe (Ed.), Yas danışmanlı̆̆ı içinde (ss. 1-50). Anı Yayıncilik.

Bağcaz, A. (2017). Ankara'da yakın kaybı sonrası yas belirtilerinin yaygınlı̆̆ ve yordayıcı etmenler (sosyodemografik özellikler, yakın kaybının özellikleri, anksiyete duyarlılı̆̆ ve yetişkin ayrılık anksiyetesi ile ilişkisi) [Uzmanlık Tezi]. Hacettepe Üniversitesi.

Balcı-Çelik, S. (2011). Ergenlerin yasa karşı tutumlarının cinsiyet ve depresyon düzeyleri açısından karşılaştırılması. Illköğretim Online, 10(2), 735-742.

Bildik, T. (2013). Ölüm, kayıp, yas ve patolojik yas. Ege Tip Dergisi, 52(4), 223-229.

Bodenhorn, N., \& Skaggs, G. (2005). Development of the school counselor self-efficacy scale. Measurement and Evaluation in Counseling and Development. https://doi.org/10.1080/07481756.2005.11909766

Buyruk Genç, A. (2019). Psikolojik danışmanların etkili psikolojik danışman nitelikleri ile kültüre duyarlı psikolojik danışma yeterlikleri arasındaki ilişkide kültürel zekânın ve bilişsel esnekliğin aracı rolü [Yayımlanmamış doktora tezi]. Yıldız Teknik Üniversitesi.

Creswell, J. W. (2016). Nitel araştırma yöntemleri: Beş yaklaşıma göre nitel araştırma ve araştırma deseni. Siyasal Yayın Dağıtım.

Çiftçiler Aydın, Z. (2000). Kayıp ve yas sürecinde sanatla zenginleştirilmiş grup müdahale programının etkililiğinin incelenmesi [Yayımlanmamış yüksek lisans tezi]. Bahçeşehir Üniversitesi.

Dowdney, L. (2000). Annotation: Childhood bereavement following parental death. Journal of Child Psychology and Psychiatry, 41(7), 819-830. https://doi.org/10.1017/S0021963099006216

Elizur, E., \& Kaffman, M. (1983). Factors influencing the severity of childhood bereavement reactions. American Journal of Orthopsychialry, 53(4), 668-676. https://doi.org/10.1111/j.1939-0025.1983.tb03410.x

Frankl, V. E. (1996). Duyulmayan anlam çı̆̆lı̆̆ı-Psikoterapi ve hümanizm. (Çev. S. Budak). Öteki Yayınevi (Orijinal çalışma 1978 yılında yayımlandı).

Freud, S. (1917). Mourning and melancholia. The Standard Edition of the Complete Psychological Works of Sigmund Freud, Volume XIV (1914-1916): On the History of the Psycho-Analytic Movement, Papers on Metapsychology and Other Works, 237-258.

Furman, E. (1983). Studies in childhood bereavement. The Canadian Journal of Psychiatry, 28(4), $241-247$. https://doi.org/10.1177/070674378302800401

Genlik, Ö. (2012). Yas süreci ve yas sürecindeki kişilerin depresyon ve anksiyete düzeylerinin incelenmesi [Yayımlanmamış yüksek lisans tezi]. İstanbul Arel Üniversitesi.

Gizir, C. A. (2006). Bir kayıp sonrasında zorluklar yaşayan üniversite öğrencilerine yönelik bir yas danışmanlığ 1 modeli. Mersin Üniversitesi Eğitim Fakültesi Dergisi, 2(2), 195-213.

Gündüz, B. \& Çelikkaleli, Ö. (2009). Okul psikolojik danışmanlarında mesleki yetkinlik inancı. Mersin Üniversitesi Ĕ̈itim Fakültesi Dergisi, 5(1), 119-133.

Güven, M., Kısaç, İ., Ercan, L. \& Yalçın, İ. (2009). Türk Psikolojik Danışma ve Rehberlik Dergisinde yayınlanan makalelerin çeşitli özellikler açısından incelenmesi. Türk Psikolojik Danışma ve Rehberlik Dergisi, 4(31), 80-87.

Henwood, K. L. (1996). Qualitative inquiry: Perspectives, methods and psychology. In J. T. E. Richardson (Ed.), Handbook of qualitative research methods for psychology and social sciences (pp. 25-40). BPS and Blackwell.

Kalay-Usta, T. (2020). Psikolojik danışmanların etkili psikolojik danışman nitelikleri ile ruh sağlı̆̆ı süreklilikleri arasındaki ilişkide kariyer uyumluluğunun aracı rolü [Yayımlanmamış doktora tezi]. Yıldız Teknik Üniversitesi.

Koyuncu, Ö. (2015). Ebeveyn kaybr yaşayan kişilerde psikolojik esneklik tepkisinin psiko-sosyal belirleyicileri: Kaybın koşulları, kişinin kendine, dünyaya, geleceğe yönelik algisı, algılanan sosyal destek ve başa çıkma stratejileri [Yayımlanmamış yüksek lisans tezi]. Hacettepe Üniversitesi.

Kurşuncu, M. A. (2017). Bilişsel davranışçı terapiler açısından yas. Ö. Erdur-Baker \& İ. Aksöz-Efe (Ed.), Yas danışmanlı̆̆

Külahçığlu, E. (2017). Yas danışmanlığı. Ö. Erdur-Baker \& İ. Aksöz-Efe (Ed.), Yas Danışmanlığı içinde (ss. 113-149). Anı Yayıncilik.

Larson, L. M., Suzuki, L. A., Gillespie, K. N., Potenza, M. T., Bechtel, M. A., \& Toulouse, A. L. (1992). Development and validation of the counseling self-estimate inventory. Journal of Counseling Psychology, 39(1), 105-120. https://doi.org/10.1037/0022-0167.39.1.105

Noppe, I. C., \& Noppe, L. D. (2004). Adolescent experiences with death: Letting go of immortality. Journal of Mental Health Counseling, 26(2), 146. https://doi.org/10.17744/mehc.26.2.py2tk0kmay1ukc3v

Padır, M. A. \& Erdur-Baker, Ö. (2017). Psikolojik danışmanların kendi yasları ve öz bakım. Ö. Erdur-Baker \& İ. Aksöz-Efe (Ed.), Yas danışmanlı̆̆

Pickhard, C. E. (1996). Keys to single parenting. Barrons Educational Series Incorporated. 
Raveis, V. H., Siegel, K., \& Karus, D. (1998). Children's psychological distress following the death of a parent. Journal of Youth and Adolescence, 28(2), 165-180. https://doi.org/10.1023/A:1021697230387

Seçer, İ., Ay, İ., Ozan, C. \& Yılmaz, Y. (2014). Rehberlik ve psikolojik danışma alanındaki araştırma eğilimleri: Bir içerik analizi. Türk Psikolojik Danışma ve Rehberlik Dergisi, 5(41), 49-60.

Senter, K. E., \& Caldwell, K. (2002). Spirituality and the maintenance of change: A phenomenological study of women who leave abusive relationships. Contemporary Family Therapy, 24(4), 543-564. https://doi.org/10.1023/A:1021269028756

Stebnicki, M. A. (2007). Empathy fatigue: Healing the mind, body, and spirit of professional counselors. American Journal of Psychiatric Rehabilitation, 10(4), 317-338. http://doi.org/10.1080/15487760701680570

Strauss, A., \& Corbin, J. (1998). Basics of qualitative research: Techniques and procedures for developing grounded theory. Sage Publications, Inc.

Stroebe, M., \& Schut, H. (1999). The dual process model of coping with bereavement: Rational and description. Death Studies, 23, 197-224. https://doi.org/10.1080/074811899201046

Şenelmiş, H. (2006). Ankara Üniversitesi Kriz Merkezine başvuran yas olguları üzerine bir çalışma [Yayımlanmamış yüksek lisans tezi]. Ankara Üniversitesi.

Walsh, F., \& McGoldrick, M. (Eds.). (1991). Living beyond loss: Death in the family. W. W. Norton \& Company.

Wardle, E. A., \& Mayorga, M. G. (2016). Burnout among the counseling profession: A survey of future professional counselors. i-manager's Journal on Educational Psychology, 10(1), 9-15.

Worden, J. W. (1996). Children in grief: When a parent dies. Guilford Press.

Worden, J. W. (2018). Grief counseling and grief theraphy: A handbook for the mental health practitioner. Springer Pub.

Yalom, I. (1999). Varoluşçu Psikoterapi. (Çev. Z. İ. Babayiğit). Kabalcı Yayınevi. (Orijinal çalışma 1980 yılında yayımlandi.).

Yıldırım, A. \& Şimşek, H. (2011). Sosyal bilimlerde nitel araştırma yöntemleri. Seçkin Yayıncılık.

Yıldı,, S. A. (2004). Çocuk, ölüm ve kayıp. Balıkesir Üniversitesi Sosyal Bilimler Dergisi, 11, 125-144.

Yıldız, Y. (2017). Tek ebeveynli çocukların yaşam deneyimleri [Yayımlanmamış doktora tezi]. İstanbul Üniversitesi.

Zara, A. (2011). Kayıplar, yas tepkileri ve yas süreci. A. Zara (Ed.), Yaşadıkça psikolojik sorunlar ve başa çıkma yolları içinde (ss. 73-90). İmge Kitabevi.

Zhang, L., Ren, Z., Jiang, G., Hazer-Rau, D., Zhao, C., Shi, C., Lai, L., \& Yan, Y. (2021). Self-oriented empathy and compassion fatigue: The serial mediation of dispositional mindfulness and counselor's selfefficacy. Frontiers in Psychology, 11, 613908. https://doi.org/10.3389/fpsyg.2020.613908 


\section{EXTENDED ABSTRACT}

\section{INTRODUCTION}

Death, a universal phenomenon, is an inevitable reality of life. The grief process, which comes with intense pain and sadness due to death, is the most shocking life event that individuals face in their lives. Grief is a multidimensional difficult process that concerns every aspect of the life of an individual who has bereavement. Grief process and grief counseling, which has been discussed in the related literature in recent years, has been a focus on attention in psychological help profession. The concept of grief was first discussed by Freud in his work 'Mourning and Melancholia'. Later, Kübler-Ross, Rondo and Lindemann handled the concept of grief and defined the stages in the post-death grief process. Especially with Worden's work, the grief concept showed itself in the therapeutic context in the counseling process. In the related literature, it is seen that the counseling process focuses more on the traumatic and complex grief processes and the importance of getting professional help and psychological counseling is emphasized in adapting individuals to the new life without the presence of the lost person. However, research, publications and practice related to grief counseling are limited in Turkey, and they are mostly carried out on children, adolescents and parents. Consequently, there is a need to evaluate how psychological counselors deal with the subject of 'grief counseling', what kind of studies they have done in this topic and their perceptions about grief counseling. Examining the definitions of the grief process of psychological counselors, their feelings, thoughts and experiences about themselves in the professional context, and their evaluations of their knowledge, skills and competencies in grief counseling in terms of psychological counseling constitute the problem of the study.

\section{METHOD}

The phenomenological method in the qualitative research tradition was used to realize the purpose of the research. Research aims to describe, interpret and understand a phenomenon with a small study group (Henwood, 1996). The phenomenological method in this tradition aims to focus on the meanings experienced by the participants, rather than defining obvious events or behaviors (Senter \& Caldwell, 2002).

Ten counselors took part in the study group, which was created with the criterion sampling method. The criteria for the participants to reside in Istanbul, to see active clients in the psychological counseling center, and to have at least two years of professional experience were considered in the formation of the study group. Four of the participants are female and six of them are male. Two of them work in the counseling center, six in the school and counseling center, two in the Counseling and Research Center and psychological counseling center. While three of them are undergraduate and five are graduate, two of them are continuing their $\mathrm{PhD}$. The average working year of the participants is twelve years.

In the research, semi-structured interview technique was used. Questions were formed by researcher to reveal participants' perceptions of grief counseling, demographic information, evaluations regarding the practice in Turkey and experiences. During the interviews, the researcher made natural observation. The psychological counselors who were reached in line with the criteria of the study were informed about the purpose and application stages of the research before the application. After necessary explanation, semi-structured individual interviews were conducted by voice recording with the permission of the participants. The interviews lasted 15-60 minutes. Descriptive analysis and content analysis were used to analyze the data. First, the interviews were deciphered, then the similarities in the expressions were determined and themes and categories were formed. Peer review (Y1ldırım \& Şimşek, 2011) included in the qualitative research method was used for the internal reliability and validity of the research. Other internal reliability steps include clarifying which questions are sought in the research and removing invalid data. On the other hand, external reliability steps are introducing the participants, including explanations about data collection and analysis methods.

\section{FINDINGS, DISCUSSION AND RESULTS}

In the study, it is noteworthy that the participants answered the question about the meaning of grief over different types of loss and they did not associate the bereavement only with death. It was seen that the participants who described grief as a situation arising after the loss associated this situation with pain in different types of loss, such as 'death, divorce, separation, loss of space, job loss, identity/childhood/youth loss' etc. They explained this situation through examples.

In their explanations about how they work when grief occurs, the participants stated that their clients express their feelings, reveal them, ensure to be realized them, look at the life effect of the mourning, apply the therapeutic approach/approaches and techniques they feel competent and intervene according to their developmental characteristics. 
It is determined that the cultural effect on grief draws attention in participants' opinion about how the process of seeking professional help regarding grief in Turkey. It is seen that there is a demand for theoretical and practical training in the expectations of the participants about grief counseling.

The opinions of participants about the tendencies of working with grief in Turkey were gathered under the themes of own grief of the counselor, existential anxiety and perception of professional/personal inadequacy. Participants noted that psychological counselors were reluctant to work with grief because they avoid facing their own deferred one. It is seen that the participants answer over their personal lives, preferences and features while they explain working trends in grief counseling in Turkey.

According to the findings of this research, in the context of the professional and personal development of the counselors working with grief, it is recommended that counselors review their existence, relationship with the grief and past grief experiences, and get supervision support. In addition, it is thought that there is a need to focus on applied education as much as theoretical education in undergraduate education. In addition, it is suggested that to investigate the counselors who have bachelor's degree and working only in schools, perceptions on the subject, experiences, evaluations regarding the application in Turkey, and plan theoretical and practical studies for the requirements to be put forward. This research is limited to the determination of psychological counselors' grief counseling phenomena according to qualitative research method.

\section{ARAŞTIRMACILARIN KATKI ORANI}

Yelda YILDIZ ÖNAL’ın araştırmaya katkı oranı \%60, Serhat Armağan KÖSEOĞLU'nun araştırmaya katkı oranı $\% 40$ 'dir.

Yelda YILDIZ ÖNAL: Araştırmanın tasarlanması, yöntemin belirlenmesi ve yazımı, verilerin toplanması, veri analizi, bulgular ve genişletilmiş özet bölümlerinin yazımı, raporlaştırma.

Serhat Armağan KÖSEOĞLU: Giriş, tartışma ve sonuç, kaynakça bölümlerinin yazımı ve veri analizi.

\section{ÇATIŞMA BEYANI}

Yazarlar, araştırmada herhangi bir kişi ya da kurum ile finansal ya da kişisel yönden bağlantı kurulmadığını ve araştırmada çıkar çatışmasının bulunmadığını beyan ederler.

\section{ARAŞTIRMANIN ETIK İZNi}

Yapılan bu çalışmada "Yükseköğretim Kurumları Bilimsel Araştırma ve Yayın Etiği Yönergesi” kapsamında uyulması gerektiği belirtilen tüm kurallara uyulmuştur. Yönergenin ikinci bölümü olan "Bilimsel Araştırma ve Yayın Etiğgine Aykırı Eylemler” başlığı altında belirtilen eylemlerden hiçbiri gerçekleştirilmemiştir.

\section{Etik kurul izin bilgileri}

Etik değerlendirmeyi yapan kurul adı: İstanbul Medipol Üniversitesi Sosyal Bilimler Bilimsel Araştırmalar Etik Kurulu Başkanlığ

Etik değerlendirme kararının tarihi: 14/08/2020

Etik değerlendirme belgesi sayı numarası: 43037191-604.01.01-E.38098 